\title{
PEMANFAATAN LINGKUNGAN SEBAGAI SUMBER BELAJAR ANAK
}

\author{
Irfatul 'Ulum \\ TK AA 16 Tominuku Wolwal \\ E-mail: irfha.ulum@yahoo.co.id)
}

\begin{abstract}
Abstrak
Berawal dari adanya masalah keterbatasan media dan sumber belajar anak, guru memanfaatkan berbagai bahan yang ada di lingkungan sekitar sebagai media dan sumber untuk keberlangsungan kegiatan belajar mengajar.

Kegiatan dalam upaya pemanfaatan lingkungan sebagai media dan sumber belajar dilakukan dengan melibatkan para guru, siswa dan orangtua dengan ikut serta dalam pembuatan media serta melibatkan siswa untuk terus aktif dalam pelaksanaan KBM.

Akibat dari proses KBM dengan memanfaatkan lingkungan adalah masalah keterbatasan media dan sumber belajar dapat teratasi serta anak dapat berperan aktif dalam terlaksananya kegiatan belajar mengajar.
\end{abstract}

Kata Kunci: manfaat lingkungan, sumber belajar anak

\begin{abstract}
Due to the problem in lacking of media and students' learning sources, teachers made use of various objects in the surroundings as the media and sources for the sake of teaching learning activity.

The activity of utilizing environments as learning media and sources involved the teachers, students, and parents to take part in the media making process. Students were also involved to keep being active in the teaching-learning process (KBM).

With the utilization of environment in teaching-learning process (KBM), the problem of lacking media and learning source was solved and students were actively taking part in the teaching-learning process (KBM).
\end{abstract}

Keywords: environment benefit, students' learning source

\section{PENDAHULUAN}

Anak usia dini merupakan usia emas (the golden age) yang sangat potensial untuk melatih dan mengembangkan berbagai potensi multi kecerdasan yang dimiliki anak (Harun Rasyid, 2009:64). Menurut NAEYC (National Assosiation Education for Young Children) anak usia dini adalah sekelompok individu yang berada pada rentang usia antara 0-8 tahun, pada usia tersebut manusia sedang berada dalam proses pertumbuhan dan perkembangan (Sofia Hartati, 2005:7).
Pendidikan anak usia dini bertujuan untuk mengembangkan seluruh potensi anak (the whole child) agar kelak dapat berfungsi sebagai manusia yang utuh sesuai falsafah suatu bangsa (Slamet Suyanto, 2005:5). Pengembangan potensi pada anak dapat dilakukan melalui pemberian stimulus yang tepat. Pemberian stimulus bagi anak usia dini berbeda dengan pemberian bagi orang dewasa. Hal tersebut dikarenakan anak usia dini bukan merupakan bentuk mini dari orang dewasa, anak usia dini memiliki karakteristik yang berbeda dengan orang dewasa. Anak usia 
dini sangat aktif, dinamis, antusias, dan hampir selalu ingin tahu terhadap apa yang dilihat dan didengarnya (Sofia Hartati, 2005:8).

Potensi anak usia dini yang perlu dikembangkan mencakup seluruh aspek kemampuan dasar, yakni aspek fisik motorik, kognitif, sosio-emosianal, bahasa, seni serta nilai agama dan moral. Berbagai upaya perlu dilakukan untuk mengembangkan aspek-aspek perkembangan anak tersebut. Termasuk penyediaan media dan sumber belajar yang menunjang pengembangan berbagai aspek perkembangan anak.

Berdasarkan kisah yang dialami di TK Artha Asih 16 Tominuku Wolwal yang merupakan TK swasta yang ada di Kecamatan Alor Barat Daya, Kabupaten Alor, guru menemukan berbagai hambatan terkait masalah kurangnya sumber dan media pembelajaran. Meskipun TK Artha Asih 16 Tominuku Wolwal terletak tidak jauh dengan kota, masih cukup banyak keterbatasan dalam menunjang keberlangsungan KBM yang terdapat di TK ini. Dana dari pemerintah serta yayasan yang sudah lama tidak turun, serta tidak dipungut biaya bagi para peserta didik membatasi guru untuk menyediakan berbagai keperluan yang menunjang KBM.

Bahan yang menunjang proses kegiatan belajar mengajar di kelas yang harusnya lengkap, banyak yang tidak terpenuhi. Pembuatan alat peraga yang menunjang pembelajaran juga sulit dilakukan karena terbatasnya sumber bahan yang tersedia. Bahkan kertas untuk membuat LKA bagi anak juga sangat terbatas.

Guru dituntut agar lebih kreatif dalam menyiapkan media dan sumber belajar yang diperlukan oleh anak. Adanya inovasi dengan menggunakan berbagai bahan yang ada di alam sekitar sangat diperlukan untuk menunjang keberlangsungan kegiatan belajar mengajar.

\section{Pengertian Lingkungan}

Menurut Muhammad Efendi (2013) lingkungan adalah sesuatu gejala alam yang ada disekitar kita, dimana terdapat interaksi antara faktor biotik (hidup) dan faktor abiotik (tak hidup) dimana lingkungan menyediakan rangsangan (stimulus) terhadap individu dan sebaliknya individu memberikan respons terhadap lingkungan.

Sujana (Sri Winarni, 2012), menuliskan bahwa pengertian sumber belajar bisa diartikan secara sempit dan secara luas, penegrtian secara sempit diarahkan pada bahan-bahan cetak sedangkan secara luas tidak lain adalah daya yang bisa dimanfaatkan guna kepentingan proses belajar mengajar, baik secara langsung maupun tidak langsung.

Menurut Sri Winarni (2012) lingkungan yang ada di sekitar anak-anak merupakan salah satu sumber belajar yang dapat dioptimalkan untuk pencapaian proses hasil pendidikan yang berkualitas. Jumlah sumber belajar yang tersedia di lingkungan ini tidaklah terbatas, sekalipun pada umumnya tidak dirancang secara sengaja untuk kepentingan pendidikan.

\section{Jenis lingkungan sebagai sumber pembelajaran}

Semua lingkungan yang ada disekitar kita bisa digunakan sebagai media pembelajaran (Muhammad Efendi,2013). Dari semua lingkungan yang dapat digunakan dalam proses pendidikan dan pengajaran secara umum dapat dikategorikan menjadi tiga macam lingkungan belajar yakni lingkungan sosial, lingkungan alam dan lingkungan buatan.

a. Lingkungan Sosial

Lingkungan sosial sebagai sumber belajar berkenaan dengan interaksi manusia dengan kehidupan bermasyarakat, seperti organisasi sosial, adat dan kebiasaan, mata pencaharian, kebudayaan, pendidikan, kependudukan, struktur pemerintahan, agama dan sistem nilai. Lingkungan sosial tepat digunakan untuk 
mempelajari ilmu-ilmu sosial dan kemanusiaan.

b. Lingkungan Alam

Lingkungan alam atau lingkungan fisik adalah segala sesuatu yang sifatnya alamiah, seperti sumber daya alam (air, hutan, tanah, batu-batuan), tumbuhtumbuhan dan hewan (flora dan fauna), sungai, iklim, suhu, dan sebagainya.

Lingkungan alam sifatnya relatif menetap, oleh karena itu jenis lingkungan ini akan lebih mudah dikenal dan dipelajari oleh anak. Sesuai dengan kemampuannya, anak dapat mengamati perubahan-perubahan yang terjadi dan dialami dalam kehidupan sehari-hari, termasuk juga proses terjadinya.

Dengan mempelajari lingkungan alam ini diharapkan anak akan lebih memahami gejala-gejala alam yang terjadi dalam kehidupannya sehari-hari, lebih dari itu diharapkan juga dapat menumbuhkan kesadaran sejak awal untuk mencintai alam, dan mungkin juga anak bisa turut berpartisipasi untuk menjaga dan memelihara lingkungan alam.

c. Lingkungan Buatan

Lingkungan buatan adalah lingkungan yang sengaja diciptakan atau dibangun manusia untuk tujuan-tujuan tertentu yang bermanfaat bagi kehidupan manusia. Lingkungan buatan antara lain adalah irigasi atau pengairan, bendungan, pertamanan, kebun binatang, perkebunan, penghijauan, dan pembangkit tenaga listrik.

\section{Nilai-Nilai Lingkungan sebagai Sumber Belajar}

Lingkungan yang ada di sekitar anak merupakan salah satu sumber belajar yang dapat dioptimalkan untuk pencapaian proses dan hasil pendidikan yang berkualitas bagi anak usia dini.

a. Lingkungan menyediakan berbagai hal yang dapat dipelajari anak. Jumlah sumber belajar yang tersedia di lingkungan ini tidaklah terbatas, sekalipun pada umumnya tidak dirancang secara sengaja untuk kepentingan pendidikan. Sumber belajar lingkungan ini akan semakin memperkaya wawasan dan pengetahuan anak karena mereka belajar tidak terbatas oleh empat dinding kelas. Selain itu kebenarannya lebih akurat, sebab anak dapat mengalami secara langsung dan dapat mengoptimalkan potensi panca inderanya untuk berkomunikasi dengan lingkungan tersebut.

Kegiatan

belajar dimungkinkan akan lebih menarik bagi anak sebab lingkungan menyediakan sumber belajar yang sangat beragam dan banyak pilihan. Kegemaran belajar sejak usia dini merupakan modal dasar yang sangat diperlukan dalam rangka penyiapan masyarakat belajar (learning societes) dan sumber daya manusia di masa mendatang.

b. Pemanfaatan lingkungan menumbuhkan aktivitas belajar anak (learning activities) yang lebih meningkat.

Penggunaan cara atau metode yang bervariasi merupakan tuntutan dan kebutuhan yang harus dipenuhi dalam pendidikan untuk anak usia dini. Begitu banyaknya nilai dan manfaat yang dapat diraih dari lingkungan sebagai sumber belajar dalam pendidikan anak usia dini bahkan hampir semua tema kegiatan dapat dipelajari dari lingkungan. Namun demikian diperlukan adanya kreativitas dan jiwa inovatif dari para guru untuk dapat memanfaatkan lingkungan sebagai sumber belajar.

Lingkungan merupakan sumber belajar yang kaya dan menarik untuk anak-anak. Lingkungan mana pun bisa menjadi tempat yang menyenangkan bagi anak-anak.

Jika pada saat belajar di kelas anak diperkenalkan oleh guru mengenai binatang, dengan memanfaatkan lingkungan anak 
akan dapat memperoleh pengalaman yang lebih banyak lagi. Dalam pemanfaatan lingkungan tersebut guru dapat membawa kegiatan-kegiatan yang biasanya dilakukan di dalam ruangan kelas ke alam terbuka dalam hal ini lingkungan. Namun jika guru menceritakan kisah tersebut di dalam ruangan kelas, nuansa yang terjadi di dalam kelas tidak akan sealamiah seperti halnya jika guru mengajak anak untuk memanfaatkan lingkungan.

Memanfaatkan lingkungan sekitar dengan membawa anak-anak untuk mengamati lingkungan akan menambah keseimbangan dalam kegiatan belajar. Artinya belajr tidak hanya terjadi di ruangan kelas namun juga di luar ruangan kelas dalam hal ini lingkungan sebagai sumber belajar yang sangat berpengaruh terhadap perkembangan fisik, keterampilan sosial, dan budaya, perkembangan emosional serta intelektual.

\section{IMPLEMENTASI}

Pada persoalan tersebut, inovasi menggunakan berbagai media dan sumberyang ada di lingkungan sekitar sangat diperlukan. Inovasi penting dilakukan untuk menunjang keberlangsungan kegiatan belajar mengajar. Guru dituntut agar lebih kreatif dalam menyiapkan sumber belajar yang diperlukan oleh anak dengan memanfaatkan berbagai bahan yang ada di lingkungan.

Menurut Sri Winarni (2012) lingkungan yang ada di sekitar anakanak merupakan salah satu sumber belajar yang dapat dioptimalkan untuk pencapaian proses hasil pendidikan yang berkualitas. Jumlah sumber belajar yang tersedia di lingkungan ini tidaklah terbatas, sekalipun pada umumnya tidak dirancang secara sengaja untuk kepentingan pendidikan.
Karena keterbatasan bahan mengajar yang ada, seusai sekolah seringkali guru mencari biji-bijian, kerang serta benda-benda lain yang dapat digunakan untuk menunjang keberlangsungan kegiatan belajar mengajar. Terkadang guru juga meminta anak-anak untuk membawa bahan-bahan yang ada di sekitar rumah mereka yang dapat digunakan untuk kegiatan pembelajaran keesokan harinya. Pernah suatu ketika, guru juga meminta kepada orangtua anak untuk ikut serta dalam menyediakan media belajar bagi anak. Guru meminta para orangtua untuk membuat balok-balok dari potongan kayu, selain itu guru juga meminta kepada orangtua untuk membuat potongan bambu yang dapat digunakan oleh anak untuk belajar membilang.

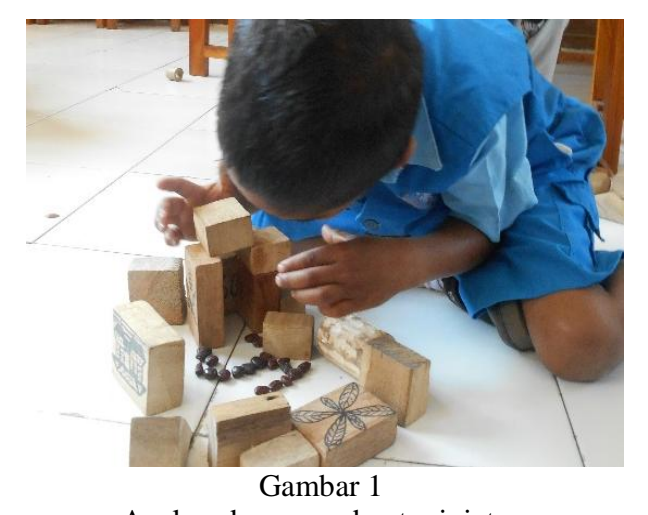

Anak sedang membuat miniatur bawah laut dari balok

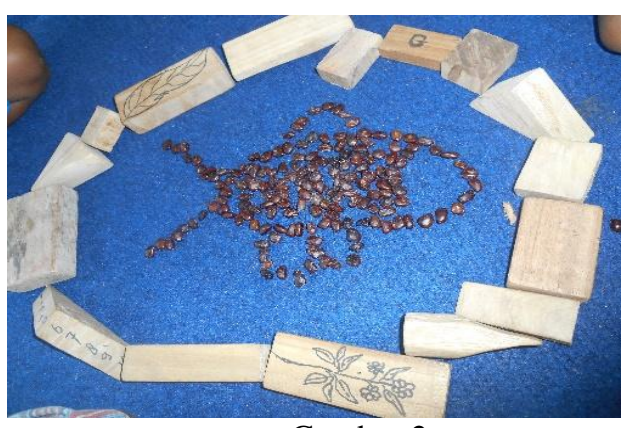

Gambar 2.

Anak membuat bentuk ikan di dalam aquarium dari biji asam

Pada saat kegiatan pembelajaran berlangsung dengan tema binatang, guru meminta anak untuk membawa biji-biji 
asam untuk digunakan anak membuat ikan-ikan di dalam aquarium yang bertujuan untuk mengembangkan kemampuan motorik halus anak. Aquarim yang dibuat oleh anakpun menggunakan balok yang telah dibuat oleh orangtua anak. Lalu usai mengasah motorik halus, anak diminta untuk mengumpulkan bijibiji tersebut dan membilang berapa jumlah biji yang telah digunakan. Kegiatan tersebut bertujuan untuk mengembangkan kemampuan kognitif anak. Kegiatan yang menyenangkan meski di dalamnya bertujuan untuk mengembangkan berbagai aspek perkembangan anak.

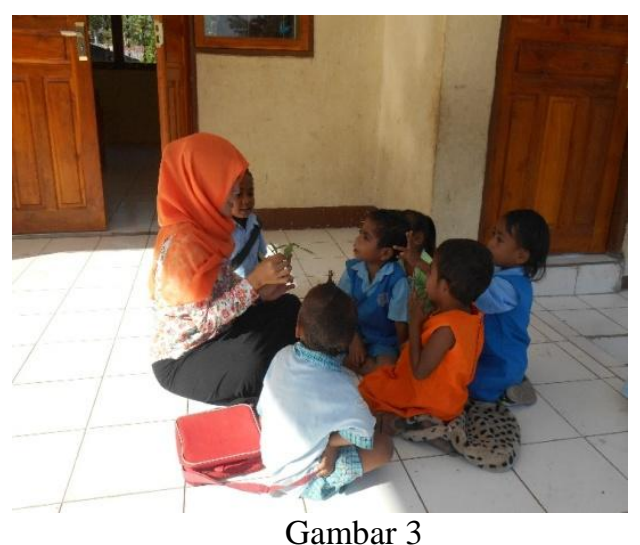

Memanfaatkan tanaman sebagai sumber belajar

Pada saat KBM dengan tema tanaman, guru menggunakan sumber belajar yang ada di lingkungan sekolah. Berbagai jenis daun-daunan serta bunga digunakan oleh guru untuk mengajarkan anak membilang dan mengenal warna. Kegiatan membilang dilakukan dengan menghitung daun yang ada di ranting yang telah diambil, serta kegiatan mengenal warna dilakukan dengan membedakan warna daun serta bungabunga yang ada di sekitar anak.

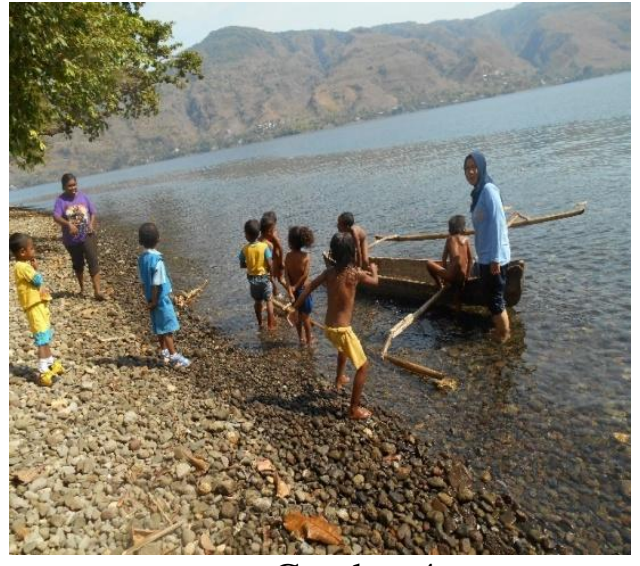

Gambar 4

Pembelajaran di Pantai

Alam sekitar sangat berperan untuk berlangsungnya kegiatan belajar mengajar bagi anak-anak. Bermainmain di lapangan milik SD seringkali dilaksanakan, disana anak akan bermain lempar tangkap bola, menaiki bebatuan, permainan sunda manda, serta bermain lompat tali dengan menggunakan serat-serat pohon. Guru juga pernah mengajak anak-anak untuk berjalan-jalan di pasar yang ada di Desa Wolwal yang hanya ada satu kali dalam seminggu.

$\begin{array}{cl}\begin{array}{c}\text { Suatu ketika, guru juga } \\ \text { mengajak }\end{array} & \text { anak-anak }\end{array}$ melaksanakan KBM di pantai karena lingkungan tempat tinggal dan sekolah anak adalah pesisir. Disana anak tidak hanya belajar mengenal lingkungan sekitarnya, namun anak-anak juga bersuka ria dengan bermain-main di laut. Tidak ada kecemasan dalam diri para guru karena anak sudah begitu akrab dengan lingkungan pantai.

Belajar menanam pohon jagung dan tanaman hias juga dilakukan di halaman sekolah. Tidak hanya itu, anak juga diajak untuk merawat tanaman dengan menyiram dan ikut serta membersihkan rumput di halaman sekolah. Hal tersebut dilakukan oleh anak-anak dengan antusias yang cukup besar.

\section{KESIMPULAN}


Berdasarkan pengalaman yang telah dialami di TK Artha Asih 16 Tominuku Wolwal, guru menemukan berbagai hambatan terkait masalah kurangnya sumber dan media pembelajaran. Hal tersebut dilatarbelakangi karena dana dari pemerintah serta yayasan yang sudah lama tidak turun, serta tidak dipungut biaya bagi para peserta didik membatasi guru untuk menyediakan berbagai keperluan yang menunjang KBM.

Oleh karena itu, adanya inovasi dengan menggunakan berbagai bahan yang ada di lingkungan sekitar sangat diperlukan untuk menunjang keberlangsungan kegiatan belajar mengajar. Guru dituntut agar lebih kreatif dalam menyiapkan media dan sumber belajar yang diperlukan oleh anak yang bersumber dari lingkungan sekitar. Lingkungan yang ada di sekitar anak-anak merupakan salah satu sumber belajar yang dapat dioptimalkan untuk pencapaian proses hasil pendidikan yang berkualitas.

Penggunaan bahan dan media yang bersumber dari lingkungan sekitar anak seperti biji-bijian, kerang, daun-daun kering, potongan-potongan kayu dilakukan oleh guru sebagai upaya untuk menunjang KBM. Selain itu guru juga melaksanakan kegiatan di luar kelas seperti lapangan, kebun, pasar dan laut.

Hidup dalam keterbatasan, bersatu dengan alam tak pernah menjadi menjadi penghalang untuk kebahagiaan. Justru keterbatasan melahirkan semangat untuk membentuk pribadi menjadi lebih kreatif dan aktif serta menumbuhkan sifat cinta lingkungan dengan memanfaatkan berbagai media dan sumber belajar yang ada di lingkungan sekitar.

\section{DAFTAR PUSTAKA}

Harun Rasyid, dkk. (2009). Asesmen Perkembangan Anak Usia Dini. Yogyakarta: Multi Pressindo.
Muhammad Efendi (2013). Lingkungan Sebagai Media Pembelajaran. Di unduh di http://efendi08.blogspot.co.id/2013/0 3/lingkungan-sebagai-mediapembelajaran.html pada tanggal 21 Maret 2016.

Pristiadi Utomo (2011). Pemanfaatan Lingkungan sebagai Sumber Belajar Anak Usia Dini. Di unduh di https://ilmuwanmuda.wordpress.com /pemanfaatan-lingkungan-sebagaisumber-belajar-untuk-anak-usiadini/pada tanggal 21 Maret 2016.

Slamet Suyanto. (2005). Konsep Dasar Pendidikan Anak Usia Dini. Jakarta: Depdiknas.

Sofia Hartati. (2005). Perkembangan Belajar Pada Anak Usia Dini. Jakarta: Depdiknas.

Sri Winarni. (2012). Lingkungan sebagai Sumber Belajar. Di unduh di http://diarywiens.blogspot.co.id/201 2/09/lingkungan-sebagai-sumberbelajar_11.html pada tanggal 21 Maret 2016. 